\title{
TIESĪBU NORMU INTERPRETĀCIJAS NOZĪME TIESĪBU NORMU KVALITĀTES SEKMĒŠANĀ: KRIMINĀLLIKUMA 191. PANTA GADĪJUMS
}

\section{IMPORTANCE OF INTERPRETATION OF LEGAL NORMS TO PROMOTE QUALITY OF LEGAL NORMS: THE CASE OF SECTION 191 OF THE CRIMINAL LAW OF THE REPUBLIC OF LATVIA}

\author{
Toms Čevers, Mg. iur. \\ Latvijas Universitātes Juridiskās fakultātes doktorants
}

\begin{abstract}
Summary
The article reveals the evolution of the Section 191 "Unauthorised Activities with Goods and Other Valuable Property Subject to Customs Clearance" of the Criminal Law of the Republic of Latvia. Author draws the attention to significant changes in grammatical, systematic and teleological interpretation of the scope of this legal norm. It has been found that current criminal offence no longer provides for a criminal liability for unlawful activities with smuggled goods in the interior market but it distinctly criminalizes violations of the rules of customs procedures when the goods have been previously imported lawfully.
\end{abstract}

Atslēgvārdi: tiesību normu interpretācija, muitošanai pakḷauta prece, muitas procedūra.

Keywords: interpretation of legal norms, goods subject to customs clearance, customs procedure.

\section{Ievads}

No tiesiskās noteiktības principa kā vispārēja tiesību principa, kas paredz tiesiskā regulējuma noturību un prognozējamību tiesiskajās attiecībās, atvasināma arī tāda likumdevējam izvirzāma prasība, ka tiesiskais regulējums tiek grozīts tikai tad, ja tam ir pamats, un tikai tādā mērā, kādā iepriekšējais tiesiskais regulējums vairs neatbilst sabiedrības vajadzībām. ${ }^{1}$

Bieža grozījumu izdarīšana tādā konservatīvā normatīvā tiesību aktā kā Krimināllikums ${ }^{2}$ (turpmāk - KL), nepārdomāti korigeèjot noziedzīgu nodarījumu sastāvu formulējumus, ne tikai grauj tā autoritāti, bet arī var nonākt pretrunā ar tā 1. panta pirmajā daḷā nostiprināto krimināltiesību principu nullum crimen sine lege (latīnu val. "nav nozieguma bez likuma"), proti, ka pie kriminālatbildības

\footnotetext{
1 Nikuḷceva I. Likums un tā grozijumi. Jurista Vārds, 08.04.2008., Nr. 14, 3. lpp.

2 Krimināllikums: LV likums. Pieņemts 17.06.1998. Latvijas Vēstnesis, 1998, Nr. 199/200.
} 
persona saucama tikai par KL tieši paredzēta noziedzīga nodarījuma izdarīšanu. Kā zināms, konstitucionālā ranga tiesības zināt savas tiesības ietver arī prasību par tiesību normu skaidrību, paredzot, lai no krimināltiesību normām būtu saprotams, kas ir aizliegts un kas ir tiesību normas adresāts, iespējamas šaubas kliedējot lietpratēja konsultācijā. ${ }^{3}$ Tādēḷ nepietiekami skaidra tiesību norma ir nekvalitatīva, jo apgrūtina tās piemērošanu un attiecīgi - tās mērḳa sasniegšanu.

Tiesiskajā realitātē krimināltiesību normas skaidrības problēma spilgti novērojama KL 191. panta "Neatḷautas darbības ar muitošanai pakḷautām precēm" kontekstā sakarā ar tā pirmās daļas dispozīcijā izdarītajiem grozījumiem. Kā norādijusi Dr. iur. Valentija Liholaja, apkopojot tiesu praksi krimināllietās par noziedzīgiem nodarījumiem tautsaimniecībā, ${ }^{4}$ tiesību normu piemērotāji laika gaitā būtiski atšķirīgi izpratuši šì noziedzīgā nodarījuma sastāvu, aktualizējot nepieciešamību noteikt KL 191. panta un 221. panta "Alkoholisko dzērienu un tabakas izstrādājumu nelikumīga izgatavošana (ražošana), uzglabāšana, pārvietošana un realizācija” nošķiršanas pazīmes, ievērojot, ka daḷēji pārklājas šo noziedzīgo nodarïjumu priekšmeti.

Papildus dažādu instanču tiesas laika gaitā pieṇēmušas diametrāli atšķirīgus nolēmumus par personas izdarītā atbilstību KL 191. pantā paredzētā noziedzīgā nodarījuma sastāvam tieši tiesību normas satura atšksirīgas izpratnes dēḷ. Turklāt arī krimināltiesību pētnieki līdz šim izdarījuši atšķirīgus secinājumus par KL 191. panta saturu. Šie apstākḷi rada pamatu šaubām par šis krimināltiesību normas pietiekamu skaidrību, it sevišķi ņemot vērā, ka krimināltiesību normām pamatoti izvirzāmas augstākās juridiskās tehnikas prasības. ${ }^{5}$

Raksta turpinājumā tiks iztirzāti Latvijas Republikas Augstākās tiesas Senāta Krimināllietu departamenta nolēmumi, kuros sniegta saistoša KL 191. panta interpretācija, kas, autora ieskatā, nav novērsusi šaubas par šī noziedzīgā nodarījuma sastāva tvērumu. Autors izvērtēs, cik skaidri ir formulēts KL 191. pants tajā izdarìto grozījumu kontekstā. Ievērojot Satversmes tiesas atziṇu, ka šaubas par tiesību normas skaidrību novēršamas ar tiesību normu interpretācijas metodēm, ${ }^{6}$ tiks skaidrots, kā tiesību normu interpretācijas metožu mērḳtiecīga izmantošana sekmē tiesību normas satura pilnīgu atklāšanu.

\footnotetext{
${ }^{3}$ Hamkova D. Krimināltiesību normas skaidrība kā konstitucionāla vērtība. Grām.: Satversmē nostiprināto vērtību aizsardzība: dažādu tiesību nozaru perspektīva. Latvijas Universitātes 77. starptautiskās zinātniskās konferences rakstu krājums. Rīga: LU Akadēmiskais apgāds, 2019, 67.-68. lpp.

${ }^{4}$ Liholaja V. Ieskats noziedzīgu nodarījumu pret tautsaimniecības interesēm juridiskā izvērtējuma problemātikā. Grām.: Starptautisko un Eiropas Savienības tiesību piemērošana nacionālajās tiesās. Latvijas Universitātes 78. starptautiskās zinātniskās konferences rakstu krājums. Rīga: LU Akadēmiskais apgāds, 2020, 157. lpp.; Liholaja V. Noziedzīgie nodarījumi nodokḷu jomā (vispārīgi un arī jo īpaši izvairīšanās no nodokḷu maksāšanas, muita, akcize u. c.). 2016.-2019. Tiesu prakses apkopojums. 2020. Papīra formātā šis materiāls publiski nav pieejams; pētniece, analizējot tiesu prakses izmaiṇas un attiecīgi Krimināllikuma 191. panta evolūcijas ietekmi uz noziedzīgu nodarījumu kvalifikāciju, gan nav sniegusi savu vērtējumu kasācijas instances tiesas veiktajai tiesību normas interpretācijai.

5 Satversmes tiesas 21.02.2019. sprieduma lietā Nr. 2018-10-0103 13.2. punkts. Pieejams: https://www. satv.tiesa.gov.lv/cases/?search[number] =2018-10-0103 [aplūkots 19.12.2020.].

6 Satversmes tiesas 30.03.2011. sprieduma lietā Nr. 2010-60-01 15.2. punkts. Pieejams: https://www.satv. tiesa.gov.lv/cases/?search[number] =2010-60-01 [aplūkots 19.12.2020.].
} 


\section{Krimināllikuma 191. panta evolūcija}

KL pamata redakcijā 191. pantā bija paredzēta kriminālatbildība par tādu preču vai citu vērtību glabāšanu, pārvadāšanu, pārsūtī̌̌anu vai realizēšanu, kas Latvijas Republikā ievestas bez nepieciešamajiem dokumentiem, kuri apliecina šo vērtỉbu likumīgu pārvietošanu pāri muitas robežai. Uzsverot noziedzīgā nodarijuma priekšmeta nelegālo statusu Latvija Republikas teritorijā, šai tiesību normai tika dots nosaukums "Nelikumīgi ievestu preču un citu vērtību glabāšana un realizēšana".

Līdz šim likumdevējs vairākkārt grozījis kriminālatbildības slieksni par šajā pantā paredzētā nodarījuma izdarīšanu, kā arī revidējis sankcijas ${ }^{8}$, taču būtiskākās izmaiņas izdarītas ar 2005. gada 28. aprīḷa likumu "Grozỉjumi Krimināllikumā”", kad kapitāli tika mainīts dispozīcijā ietvertais nodarījuma formulējums. Atbilstoši panta jaunajam nosaukumam "Neațautas darbības ar muitošanai pakḷautām precēm un citām vērtībām" tajā kriminālatbildība turpmāk paredzēta par muitošanai pakḷauto preču vai citu vērtību glabāšanu, pārvadāšanu ${ }^{10}$, pārsūtī̌šnu vai realizēšanu Lat vijas Republikas muitas teritorijā bez muitas iestāžu aț̣aujas.

Konstatējams, ka atbilstoši dispozīijas jaunajai redakcijai pārformulētas tādas noziedzīga nodarījuma sastāva objektīvās puses pazīmes kā

- noziedzīga nodarijuma priekšmets;

- nodarijums.

\begin{tabular}{|c|c|c|}
\hline & \multicolumn{2}{|c|}{ KL 191. pants } \\
\hline & $\begin{array}{c}\text { redakcijā lìdz } \\
\text { 2005. gada } 31 \text {. maijam }\end{array}$ & $\begin{array}{l}\text { redakcijā no } \\
\text { 2005. gada } 1 \text {. jūnija }\end{array}$ \\
\hline & $\begin{array}{l}\text { Nelikumīgi ievestu preču un citu } \\
\text { vērtību glabāšana un realizēšana }\end{array}$ & $\begin{array}{l}\text { Neatlautas darbības ar muitošanai } \\
\text { paklautām precēm un citām vērtībām }\end{array}$ \\
\hline $\begin{array}{c}\text { Noziedzīga } \\
\text { nodarījuma } \\
\text { priekšmets }\end{array}$ & $\begin{array}{l}\text { Preces un citas vērtības, kas } \\
\text { Latvijas Republikā ievestas bez } \\
\text { nepieciešamajiem dokumentiem, } \\
\text { kuri apliecina šo vērtību likumīgu } \\
\text { pārvietošanu pāri muitas robežai }\end{array}$ & $\begin{array}{c}\text { Muitošanai pakl̦autas preces un citas } \\
\text { vērtības }\end{array}$ \\
\hline \multirow{3}{*}{ Nodarījums } & Latvijas Republika & Latvija Republikas muitas teritorija \\
\hline & \multicolumn{2}{|c|}{ glabāšana, pārvadāšana, pārsūtī̌̌ana vai realizēšana } \\
\hline & & bez muitas iestāžu atḷaujas \\
\hline
\end{tabular}

\footnotetext{
${ }^{7}$ Neizskaidrojamu iemeslu dẹl un arī neatbilstoši KL attiecīgajā laikā izmantotajai juridiskajai tehnikai minētā panta nosaukums satur šaurāku nodarījuma traktējumu nekā dispozīcija, kurā bez noziedzīgā nodarījuma glabāšanas un realizēšanas norādīta arī tā pārvadāšana un pārsūtišana.

${ }^{8}$ Sk.: Grozījumi Krimināllikumā: LV likums. Latvijas Vēstnesis, 03.032004., Nr. 34; Grozījumi Krimināllikumā: LV likums. Latvijas Vēstnesis, 27.12.2012., Nr. 202; Grozijumi Krimināllikumā: LV likums. Latvijas Vēstnesis, 19.11.2015., Nr. 227; Grozijumi Krimināllikumā: LV likums. Latvijas Vēstnesis, 15.09.2020., Nr. 178.

${ }^{9}$ Grozijumi Krimināllikumā: LV likums. Latvijas Vēstnesis, 18.05.2005., Nr. 78.

${ }^{10}$ Ar 03.09.2020. likumu "Grozijumi Krimināllikumā" tāds neaț̣autas darbības veids kā pārvadāšana aizstāts ar universālāku jēdzienu "pārvietošana", tādējādi izslēdzot jebkādas šaubas, ka tiek aptverti visi iespējamie paṇēmieni, kā tiek mainīta preču fiziska atrašanās vieta. Sk. likumprojekta anotāciju. Pieejams: http://titania.saeima.lv/LIVS13/SaeimaLIVS13.nsf/0/F9EFD5689465731CC225857E0022994E?Open Document [aplūkots 20.11.2020.].
} 
Normatīvā tiesību akta un arī tiesību normas nosaukums kā juridiskās tehnikas instruments izsaka attiecīgā tiesiskā regulējuma priekšmetu, tādējādi atvieglojot tiesību normas izpratni un likumsakarīgi - tās piemērošanu. ${ }^{11}$ Likumdevējs, mainot KL 191. panta nosaukumu, to izteicis pilnīgi citiem vārdiem, tādējādi jaunajai redakcijai signalizējot tiesību normas adresātam par izmain̄ām attiecīgo krimināltiesisko attiecību veidošanā. Jāievēro, ka tiesību normas nosaukumam kā attiecīgā normatīivā tiesību akta uzbūves konstruktīvam elementam ir sava nozìme tās sistēmiskā interpretācijā. ${ }^{12}$

KL komentāros, kas izstrādāti pēc tam, kad apskatāmie KL grozījumi bija stājušies spēkā, šì panta tvērums skaidrots pretrunīgi. Vispirms Dr. iur. Aivars Niedre norādīja, ka šajā tiesību normā paredzētā noziedzīgā nodarỉjuma objektīvo pusi veido kontrabandas cẹ̦ā ievesto muitošanai pakḷauto preču vai citu vērtību glabāšana, pārvadāšana, pārsūtî̌šna vai realizēšana bez muitas iestāžu aţ̦aujas, ${ }^{13}$ tādējādi uzturot viedokli, ka kontrabanda joprojām ir KL 191. panta noziedzīgā nodarījuma predikatīvais noziedzịgais nodarījums. Taču papildus cita starpā tieši norādìts: "Ja agrāk pantā nosauktais nodarỉjums attiecās uz nelikumīgi Latvijas Republikā ievestām precēm un citām vērtībām, tad tagad atbildība iestājas par šo nodarījumu ar muitošanai pakḷautām precēm un citām vērtībām bez muitas iestāžu atḷaujas." 14

Savukārt vēlāk, kad tiesību norma jaunajā redakcijā bija spēkā jau vairāk nekā 10 gadus, KL komentāros Dr. iur. Diāna Hamkova skaidroja, ka KL 191. panta gadījumā muitošanai pakḷautās preces Latvijas Republikas muitas teritorijā ir ievestas likumīgi, bet dispozīcijā noteiktās darbïbas ar šīm precēm ir izdarìtas bez muitas iestāžu ațaujas. ${ }^{15}$ Tādējādi ir acīmredzami norādīts, ka šis tiesību normas tvērums ir pilnīgi mainījies salīdzinājumā ar KL pamata redakciju.

Likumprojekta priekšlikumu, ar kuru tika korigéti visi trīs noziedzīgo nodarījumu sastāvi, kas tieši paredz kriminālatbildību par noziedzīgiem nodarījumiem muitas darbības jomā, iesniedza Finanšu ministrija. No tās skaidrotā secināms, ka grozījumu izdarīšanu motivējusi Latvijas Republikas pievienošanās Eiropas Savienībai (turpmāk - ES), un rezultātā Latvijas Republika iekḷāvās kopējā iekšèjā tirgū, ko raksturo brīva preču kustïba. ${ }^{16}$ Ievērojot minēto, tika norādīts, ka turpmāk Latvijas Republikas teritorijā var tikt nogādātas divu veidu preces, pirmkārt,

${ }^{11}$ Nosaukums koncentrē tiesỉbu normas piemērotāja uzmanību uz nepieciešamo un pietiekamo tiesỉbu normas saturu (Krūmiņa V., Skujiņa V. Normatīvo aktu izstrādes rokasgrāmata. Rīga: [b. i.], 2002, 21. lpp.).

${ }^{12}$ Administratīīā procesa likuma komentāri. A un B daḷa. Autoru kolektīvs. Dr. iur. J. Briedes zinātniskajā redakcijā. Rīga: Tiesu namu aǵentūra, 2013, 271. lpp.

${ }^{13}$ Krastiņš U., Liholaja V., Niedre A. Krimināltiesības. Sevišķā daḷa. 3. papild. izd. Zinātniskais redaktors prof. U. Krastiņš. Rīga: Tiesu namu ag̉entūra, 2009, 422.-423. lpp.; secināms, ka, atsaucoties uz Dr. iur. A. Niedres viedokli, tas tika atbalstîts arī citu pētnieku publikācijā (Hamkova D., Liholaja V. Nelikumīgas darbības ar alkoholiskajiem dzērieniem un tabakas izstrādājumiem: kvalifikācijas problemātika. Jurista Vārds, 28.08.2012., Nr. 35, 19. lpp.).

${ }^{14}$ A. Niedre kā Latvijas zvērinātu advokātu padomes priekšsēdētājs padalijās minētā likumprojekta apspriešanā (sk.: Latvijas zvērinātu advokātu padomes 28.12.2004. vēstule Nr. 1-31-3083 Saeimas Aizsardzības un iekšlietu komisijai. Nav publicēta. Atrodas Saeimas arhīvā).

${ }^{15}$ Krastiņš U., Liholaja V., Hamkova D. Krimināllikuma komentāri. Trešā daļa (XVIII-XXV nodaḷa). Rīga: Tiesu namu ag̣entūra, 2016, 93. lpp. Šādu viedokli bija paudis arī autors savā iepriekšèjā publikācijā (sk.: Čevers T. Kontrabandas krimināltiesiskie aspekti. Rịga: Pārdaugavas juridiskais birojs, 2015, 92.-94. lpp.).

${ }^{16}$ Latvijas Republikas Finanšu ministrijas 16.02.2005. vēstule Nr. 31-20.1/4475. Nav publicēta. Atrodas Saeimas arhīvā. 
citu dalībvalstu preces, kuru aprite ES muitas teritorijā vairs netiek kontrolēta, un, otrkārt, trešo valstu preces, kuras ir pakḷaujamas muitas kontrolei. Noziedzīgā nodarījuma priekšmetu piedāvāts raksturot kā muitošanai paḳ̣autas preces, lai uzsvērtu, ka turpmāk Latvijas Republikas teritorijā brīvi var tikt nogādātas dalībvalstu preces, kuras to pārvietošanas dēl ES nav nepieciešams muitot.

Minētajā priekšlikumā attiecībā uz KL 191. panta jauno redakciju tika norādīts, ka, ja Latvijas Republikas teritorijā tiek aizturētas preces, kas ES muitas teritorijā nonākušas, nelikumīgi šķērsojot jebkuras dalībvalsts, tajā skaitā Latvijas Republikas, un trešās valsts muitas robežu, ir piemērojams KL 191. pants. Tādējādi šis likumprojekta izstrādes materiāls liecina par KL grozījumu izstrādātāju mērḳi šajā noziedzīgā nodarījuma sastāvā saglabāt kriminālatbildību par rīcību ar kontrabandas precēm. Taču pamatojums tam, ka dispozīcija ir papildināma ar norādi par atḷaujas nesaṇemšanu rīcībai ar muitošanai pakḷautajām precēm, nav norādīts.

Ievērojot minēto, autora ieskatā, saskaņā ar turpmāk skaidroto nebija šķēršlı līdzšinējo KL 191. pantu interpretēt atbilstoši jaunajiem tiesiskajiem un faktiskajiem apstākḷiem sakarā ar Latvijas Republikas iestāšanos ES. Ja tiek saglabāts šīs tiesību normas iepriekšējais tvērums, jauns KL 191. panta formulējums nebija nepieciešams.

To, vai preces ir ievestas bez nepieciešamajiem dokumentiem, kuri apliecina to likumīgu pārvietošanu pāri muitas robežai, un arī to, vai attiecīgās preces ir muitojamas, nosaka muitas lietas regulējošie normatīvie tiesību akti noziedzīgā nodarījuma izdarīšanas brīdī. Attiecīgi, ja preču aprite ir brīva, tad arī normatīvajos tiesību aktos atḷauto darbību izdarīšanu nevar atzìt par nelikumīgu rīcību ar šīm precēm. KL 191. panta sākotnējā redakcija nebija pretrunā muitas lietu kārtībai ES. Pastāvot vienotam iekšējam tirgum, no jebkuras trešās valsts ievesta prece, apejot muitas kontroli, ir uzskatāma par nelegālu jebkurā dalībvalstī, respektīvi, par tādu, kas ievesta bez nepieciešamajiem dokumentiem, kuri apliecina tās likumīgu pārvietošanu pāri muitas robežai. Pie tam dispozīcijā nebija papildus raksturots tajā lietotais jēdziens "muitas robeža”, kas būtu par šķērsli to interpretēt kā ES muitas robežu Latvijas Republikas muitas robežas vietā, n,emot vērā, ka dalībvalsts ārējā robeža ir ES ārējās robežas daḷa.

Tādējādi arī līdz apskatāmo grozỉjumu izdarīšanai KL 191. pants neietvēra gadijjumus, kad Latvijas Republikas teritorijā tiek veiktas darbības ar tajā ievestajām citu dalībvalstu precēm. Taču tas aptvēra gadijjumus, kad Latvijas Republikas teritorijā tiek veiktas darbības ar tādām precēm, kuras tajā nogādātas no citas dalībvalsts, izmantojot brīvo preču kustību, bet kuras sākotnēji ES muitas teritorijā ievestas, nelikumīgi šķērsojot muitas robežu kādas citas dalỉbvalsts teritorijā.

\section{Latvijas Republikas Augstākās tiesas sniegtā Krimināllikuma 191. panta interpretācija}

Latvijas Republikas Augstākās tiesas Krimināllietu departaments 2018. gada 25. oktobra lēmumā lietā Nr. SKK-57/2018 ${ }^{17}$ pauda izšķirošas atziṇas noziedzīgu nodarījumu kvalifikācijai saskaṇā ar KL 191. pantu.

17 Latvijas Republikas Augstākās tiesas Krimināllietu departamenta 25.10.2018. lēmums lietā Nr. SKK57/2018 kriminālprocesā Nr. 12501000217. Pieejams: http://at.gov.lv/lv/tiesu-prakse/judikaturas-nolemumu-arhivs/kriminallietu-departaments/hronologiska-seciba?year=2018 [aplūkots 12.12.2020.]. 
Ar minēto lēmumu kasācijas instances tiesa atstāja negrozītu Ventspils tiesas 2017. gada 17. novembra spriedumu, ar kuru tika apstiprināta pirmstiesas procesā noslēgtā vienošanās par vainas atzī̌sanu un sodu, personu atzīstot par vainīgu KL 191. panta trešajā daḷā paredzētā noziedzīgā nodarījuma izdarīšanā. Konkrētajā gadijumā Latvijas Republikas teritorijā apturēta transportlīdzekḷa un tā puspiekabes apskates laikā tajā tika konstatētas speciāli sagatavotas transformatoru butaforijas, kurās bija noslēptas cigaretes ar Baltkrievijas Republikas akcīzes markām lielā apmērā. Tādējādi tika konstatēts, ka Latvijas Republikas muitas teritorijā tiek nelikumīgi, respektīvi, neievērojot trešās valsts akcīzes preču pārvietošanas kārtību, pārvadātas muitošanai pakḷautas preces - tabakas izstrādājumi.

Konkrētajā kriminālprocesā konstatējams strīds par to, vai noziedzīgais nodarījums ir kvalificējams saskaṇā ar KL 191. vai 221. pantu, ievērojot, ka abās tiesību normās paredzēta kriminālatbildība par līdzvērtīgām nelikumīgām darbībām Latvijas Republikas teritorijā cita starpā arī ar tabakas izstrādājumiem, kas ir atzīstami par muitošanai pakḷautu preci, ja tiek pārvietoti starp ES dalībvalsti un trešo valsti. Attiecīgi kasācijas instances tiesas lēmumā norādìts, ka abu noziedzīgo nodarījumu norobežošanā izšķiroši ir noskaidrot, vai konkrētajam noziedzīgā nodarījuma priekšmetam nodarijuma laikā ir bijis muitošanai pakḷautas preces statuss. Kaut arī kasācijas instances tiesa to nav tieši norādījusi, konkrētajā gadījumā tiek risināta krimināltiesību normu konkurence, ņemot vērā noziedzīgā nodarījuma priekšmeta speciālās īpašības.

Kasācijas instances tiesa atsaukusies uz minēto grozījumu likumprojekta izstrādes materiāliem, konkrētāk, uz minētajā Finanšu ministrijas vēstulē norādīto KL grozījumu pamatojumu, viennozīmīgi secinot, ka likumdevēja griba ir bijusi virzìta nevis uz to, lai pilnībā mainītu KL 191. panta noziedzīgā nodarìjuma priekšmetu, bet gan lai palielinātu ši panta tvērumu attiecībā uz tām trešo valstu precēm, kas Latvijas Republikas teritorijā nogādātas pēc tam, kad tās nelikumīgi ievestas ES teritorijā, apejot muitas kontroli uz citu dalïbvalstu un trešo valstu muitas robežām. Atsaucoties uz Savienības Muitas kodeksa normām, lēmumā skaidrots ES preces un trešās valsts preces statuss un secināts, ka ikviena prece, kas tiek ievesta ES muitas teritorijā, no to ievešanas brīža atrodas muitas uzraudzībā, kamēr vien šis preces statuss nav noskaidrots. Savukārt trešo valstu preces paliek muitas uzraudzībā, līdz tiek mainīts to statuss, tās tiek izvestas no ES muitas teritorijas vai tiek iznīcinātas. Attiecīgi skaidrots, ka muitošanai pakḷauta prece ir, pirmkārt, tāda prece, kas Latvijas Republikas teritorijā ievesta, šķērsojot ES teritorijas ārējo robežu, vienlaikus apejot muitas kontroli, un, otrkārt, ārpussavienības prece, kura Latvijas Republikas teritorijā ievesta, izejot muitas kontroli, bet kuras statuss nav mainìts, kura nav izvesta no Savienības muitas teritorijas un nav arī iznīcināta. ${ }^{18}$

Nosakot KL 191. panta noziedzīgā nodarījuma priekšmetu, kasācijas instances tiesa uzsvaru likusi uz tās atrašanos muitas uzraudzībā, aptverot visus tos gadījumus, kad iespējams nodarìt kaitējumu tautsaimniecībai, patvalìgi rīkojoties ar preci pretēji muitas noteiktajai kārtībai. Secināms, ka par muitošanai pakḷautām precēm tiek atzìtas gan nelegāli ES muitas teritorijā ievestas preces, respektīvi,

${ }^{18}$ Līdzīgi muitošanai pakḷautas preces ir definējis zv. adv. Artūrs Zvejsalnieks, proti, tādas preces, kuras ir pārvietotas starp ES muitas teritoriju un trešās valsts muitas teritoriju un kurām nav ES preces statusa (Zvejsalnieks A. Par Krimināllikuma 191. panta piemērošanu. Jurista Vārds, 17.07.2007., Nr. 29, 19. lpp.). 
kontrabandas preces, ņemot vērā, ka to muitošana nav notikusi, gan arī tādas preces, kurām piemērotā muitas procedūra nav pabeigta.

Šo viedokli Latvijas Republikas Augstākās tiesas Krimināllietu departaments nostiprināja 2018. gada 8. novembra lēmumā lietā Nr. SKK-189/2018 ${ }^{19}$, kad tika atcelts Latgales apgabaltiesas 2018. gada 10. janvāra spriedums ${ }^{20}$, ar kuru savukārt tika atcelts Rēzeknes tiesas 2017. gada 26. jülija spriedums ${ }^{21}$.

\section{Krimināllikuma 191. panta tvērums}

Konkrētajā gadījumā noziedzīgā nodarījuma pareizai kvalifikācijai vispirms ir identificējams KL 191. pantā paredzētā noziedzīgā nodarījuma priekšmets, jo tieši dispozīcijā norādītā rīcība ar to pirmšķietami liecina par nodarījuma noziedzīgumu.

Normatīvie tiesību akti nesatur muitošanai pakḷautas preces definīciju, tādēl tā ir izsecināma, vērtējot citu ar muitas lietām saistītu jēdzienu skaidrojumus un sistēmiski interpretējot muitas lietu tiesisko regulējumu. Loǵiski vērtējot, muitošanai pakḷauta ir tāda prece, kuru ir nepieciešams muitot. Savukārt muitošana ir saistīta ar muitas procedūras piemērošanu konkrētajām precēm, ievērojot, ka muitošana sākas ar preču deklarēšanu, kas atbilstoši Savienības Muitas kodeksa ${ }^{22}$ 5. panta 12. punktam ir definēta kā darbība, ar ko persona noteiktā veidā un kārtībā paziṇo par savu vēlmi precēm piemērot noteiktu muitas procedūru. Atbilstoši minētajam Muitas likuma ${ }^{23}$ 1. panta 8. punktā muitošana skaidrota kā pasākumi, kurus normatīvajos aktos noteiktajā kārtībā veic persona un muitas iestāde, piemērojot precēm muitas procedūru, reeksportu vai pagaidu uzglabāšanu.

Savukārt līdz ar deklarēto preču izlaišanu, kas definēta Savienības Muitas kodeksa 5. panta 26. punktā, muitas amatpersona atḷauj tās izmantot atbilstoši mērķiem, kas norādīti piemērotajā muitas procedūrā. N̦emot vērā, ka, preces izlaižot, muitas iestāde tās ir pārbaudījusi un to atrašanos ES muitas teritorijā atzinusi par tiesisku, ar šo brīdi preces ir atzīstamas par nomuitotām.

Tādējādi secināms, ka preces ir atzīstamas par muitošanai pakḷautām ar to ievešanu ES muitas teritorijā, jo šajā brīdī muitas iestādēm rodas pamats veikt darbības to uzraudzībai, lai novērstu iekšējā tirgus apdraudējumus, līdz šo preču izlaišanai atbilstoši tām piemērotajai muitas procedūrai.

Nav apšaubāms, ka nelikumīgi ievesta prece ir atzīstama par muitošanai pakḷautu, jo normatīvajos tiesību aktos noteiktās kārtības apiešana nevar būt par pamatu personas atbrīvošanai no pienākuma pakḷaut pārvietojamo preci muitas kontrolei. ${ }^{24}$ Atšķirīibā no spēkā esošās tiesību normas tās pamata redakcijā paredzētā noziedzīgā nodarījuma priekšmeta pazìme, ka prece ir konstatēta Latvijas Republikas teritorijā bez dokumentiem, kas apliecina tās likumīgu izcelsmi,

\footnotetext{
19 Latvijas Republikas Augstākās tiesas Krimināllietu departaments pauda arī 08.11.2018. lēmumā lietā Nr. SKK-189/2018 kriminālprocesā Nr. 11823001414. Nav publicēts.

${ }^{20}$ Latgales apgabaltiesas 10.01.2018. spriedums kriminālprocesā Nr. 11823001414. Nav publicēts.

${ }^{21}$ Rēzeknes tiesas 26.07.2017. spriedums kriminālprocesā Nr. 11823001414. Nav publicēts.

22 Eiropas Parlamenta un Padomes 09.10.2013. Regula (ES) Nr. 952/2013, ar ko izveido Savienības Muitas kodeksu. Eiropas Savienības Oficiālais Vēstnesis, L 269, 10.10.2013., 1.-101. lpp.

${ }^{23}$ Muitas likums: LV likums. Latvijas Vēstnesis, 21.06.2016., Nr. 119.

24 Tas, ka, šḳērsojot muitas robežu, preces tiek noslēptas no muitas kontroles, neatbrīvo personu no pienākuma uzrādīt attiecīgās preces muitai (sk.: Lyons T. EU Customs Law. $3^{\text {rd }}$ ed. London: Oxford University Press, 2018, p. 357).
} 
uzskatāmi norādīja uz attiecīgās preces nelegālo statusu Latvijas Republikas teritorijā, izslēdzot jebkādu pamatu polemikai par KL 191. panta piemērošanas robežām.

Tādēl, autora ieskatā, nosakot KL 191. panta tvērumu, būtiskāk ir izvērtēt, vai attiecībā uz identificēto noziedzīgā nodarījuma priekšmetu ir iespējams pārkāpt kādas muitas iestāžu aț̣aujas atbilstoši tiesību normas jaunajā redakcijā paredzētajam.

Šobrīd spēkā esošā ES muitas lietas regulējošā Savienības Muitas kodeksa 134. panta pirmajā daḷā, uz kuru atsaukusies arī kasācijas instances tiesa, noteikts, ka preces, kas ievestas ES muitas teritorijā, no to ievešanas brīža ir muitas uzraudzībā un tās var pakḷaut muitas kontrolei. Turklāt preces paliek muitas uzraudzībā tik ilgi, cik vajadzīgs, lai noteiktu to muitas statusu, un tās netiek izṇemtas no muitas uzraudzības bez muitas dienestu atḷaujas. Taču jāievēro, ka Savienības Muitas kodekss ir paredzēts tiesiskas preču aprites nodrošināšanai starp ES un trešajām valstīm. Tādēḷ 134. pantā paredzētā atḷaujas došana rīcībai ar precēm ir iespèjama tikai tādām precēm, par kurām muita tiek informēta un kurām tiek piemērota kāda muitas procedūra.

Attiecīgi saskaņā ar 198. panta 1. punkta a) apakšpunktu muitas dienesti atsavina preces, tās konfiscējot un pārdodot vai iznīcinot, cita starpā tādos gadijumos, ja nav izpildìts kāds no pienākumiem, kas ir noteikts tiesību aktos muitas jomā attiecībā uz trešo valstu preču ievešanu ES muitas teritorijā, vai ja preces nav bijušas nodotas muitas uzraudzībā. Tādējādi nepārprotami secināms, ka kontrabandas ceḷā, respektīvi, apejot muitas kontroli, ES muitas teritorijā ievestas preces ir atzīstams par tādām, kas nemaz nav uzrādītas muitai un tādēḷ nav arī faktiski saṇemtas muitas uzraudzībā.

Atbilstoši iepriekš skaidrotajam secināms, ka muitas iestādes nevar kādai personai, kura prettiesiski rīkojas ar kontrabandas precēm, dot kādu atlauju rīcībai ar tām. Nelegāli ievedamo preču izraisītais tautsaimniecības apdraudējums tiek novērsts, šìs preces konfiscējot un pēc tam pārdodot vai iznīcinot tās. Tādēḷ, autora ieskatā, nav iespējams, ka KL 191. panta noziedzīgā nodarījuma priekšmets būtu kontrabandas preces, jo pantā nav runa par rīcības nelikumību kā tādu, bet gan nepārprotami par atḷaujas nesaṇemšanu attiecīgajai rīcỉbai ar tām. Secināms, ka persona atḷauju varētu saṇemt, bet kaut kādu iemeslu dēḷ tas nav noticis. Savukārt rīcībai ar kontrabandas precēm atḷauju nevar saṇemt nekādi, jo tās ir iegūtas noziedzīga nodarījuma rezultātā, kādēl par rīcību ar tām jālemj atbilstoši Kriminālprocesa likumā noteiktajam. ${ }^{25}$

Saskaṇā ar iepriekš norādīto Savienības Muitas kodeksa 5. panta 26. punktu, preces izlaižot, muitas amatpersona atḷauj tās izmantot mērḳiem, kas norādīti tām piemērotajā muitas procedūrā. N̦emot vērā, ka tieši šajā gadījumā persona ir saistīta ar izvēlētās muitas procedūras noteikumiem, ko apstiprinājusi muitas iestādes dota atḷauja, šīs atḷaujas pārkāpumi arī veido KL 191. pantā paredzēto nodarījumu, jo no preču izlaišanas brīža valsts piekrīt, ka konkrētās preces atrodas valsts muitas teritorijā ar zināmiem noteikumiem. Tādēl, pēc autora domām, KL 191. pants piemērojams gadījumos, kad preču ievešana valsts muitas teritorijā notikusi tiesiski, bet turpmāk nav ievēroti attiecīgās muitas procedūras noteikumi. ${ }^{26}$

25 Atsevišḳas izpētes priekšmets būtu noskaidrot, kāds ir kontrabandas preču kriminālprocesuālais statuss, ko pirmšķietami var vērtēt gan lietiskā pierādỉjuma, gan noziedzīga nodarījuma izdarīšanas līdzekḷa, gan noziedzīgi iegūtas mantas, gan ar noziedzīgo nodarījumu saistītas mantas kontekstā.

${ }^{26}$ Zv. adv. Artūrs Zvejsalnieks savulaik skaidrojis, ka KL 191. pants piemērojams tajos gadijjumos, kad persona Latvijas Republikas teritorijā rīkojas ar tādām precēm, kuru statusu ES muitas teritorijā un 
Apkopojot iepriekš minēto, secināms, ka KL 221. pants ir vispārīga norma iepretī KL 191. pantam, jo pirmajā gadījumā dispozīcijas vispārīgais formulējums ietver jebkādu nelikumīgu rīcību ar alkoholiskajiem dzērieniem un tabakas izstrādājumiem, bet otrajā gadījumā ir konkretizēts aizliegums rīkoties bez attiecīgas atḷaujas saṇemšanas ar tādiem alkoholiskajiem dzērieniem un tabakas izstrādājumiem, kuriem ir piemērota kāda muitas procedūra. Tādējādi secināms, ka KL 221. pantā paredzēta kriminālatbildība par nelikumīgu rīcību ar Latvijas Republikas teritorijā esošiem alkoholiskajiem dzērieniem un tabakas izstrādājumiem, kuriem nav piemērota kāda muitas procedūra un kuri neatrodas muitas uzraudzībā.

Apskatāmajā kasācijas instances tiesas nolēmumā, tai skaidrojot KL 191. panta saturu, izšḳiroša nozīme piešḳirta tam, kas noskaidrots vēsturiskās interpretācijas metodes izmantošanas rezultātā, atklājot likumdevēja gribu, ko paudusi ministrija, kas izstrādājusi KL grozījumus.

Jāievēro, ka tiesību normu interpretācijā, mijiedarbojoties tiesību normu vēsturiskajai un teleologiskajai interpretācijas metodei, ir nodalāma likumdevēja griba no likuma gribas. Attiecīgi salīdzināms likumdevēja viedoklis un tas, kā tam izdevies šo viedokli formulēt tiesību normā, ar sociālo mērḳi, kura sasniegšanai attiecīgā tiesību norma ir paredzēta. ${ }^{27}$ Vienmēr ir jānosaka, kāda ir tiesību normas jēga šodien tā saprātīgā izpratnē, pamatojoties uz likumdevēja vēsturisko gribu, lai tiktu sasniegts saprātīgs, lietderīgs un taisnīgs rezultāts. ${ }^{28}$

Kā pamatoti norādījis Māris Leja, likumprojekta izstrādes materiāli krimināltiesību normu interpretācijā izmantojami piesardzīgi, proti, tādā mērā, kādā tie raduši pietiekami konkrētu izpausmi tiesību normas tekstā, konkrētāk, tiktāl, ciktāl tie apstiprina ar pārējām interpretācijas metodēm noskaidroto, novēršot šaubas par tiesību normas saturu. ${ }^{29}$ N̦emot vērā kriminālatbildības sevišķi represīvo raksturu, tam ir sevišķa nozīme krimināltiesībās, jo, lai sasniegtu krimināltiesību preventīvo mērḳi, personai pirms kādas darbības izdarīšanas vai bezdarbības pieļaušanas ir jāspēj prognozēt savas rīcības sekas.

Tādējādi, nosakot KL 191. panta tvērumu, tiesību sistēmas efektivitātes nodrošināšanai ir pievēršama īpaša uzmanỉba arī KL 191. panta normas sistēmiskai un teleoloğiskai iztulkošanai. Nepieciešams izsvērt konkrētā noziedzīgā nodarījuma sastāva vietu KL, lai saglabātu tiesiskā regulējuma vienotību ${ }^{30}$, un tiesību normas

kurām piemērotās muitas procedūras pabeigšanu apliecinošu dokumentu persona pēc muitas iestādes pieprasījuma nespēj uzrādīt (Savienības Muitas kodeksa 51. panta pirmā daḷa). Tādā gadījumā turpmāko rīcību ar šādām precēm nav iespējams veikt bez saskaņošanas ar muitas iestādi (Zvejsalnieks A. Par Krimināllikuma 191. panta piemērošanu. Jurista Vārds, 17.07.2007., Nr. 29, 19. lpp.). Minētais autors savu viedokli galvenokārt pamato ar jēdzienu nesaskaņotu lietojumu KL, ievērojot, ka noziedzīgā nodarījuma priekšmets vienādi nosaukts gan KL 190., gan 191. pantā, lai gan KL 190. panta priekšmets nevar būt vienīgi kontrabandas ceḷā ievestas preces.

${ }_{27}$ Par subjektīvo, objektīvo un jaukto jeb subjektīvi objektīvo tiesību normu iztulkošanas mērḳa teorijām sk.: Mel̦kisisis E. Tiesību normu iztulkošana. Rīga: Latvijas Universitāte, 2000, 6.-7., 45.-46., 48.-49. lpp.; Administratīvā procesa likuma komentāri. A un B daḷa. Autoru kolektīvs. Dr. iur. J. Briedes zinātniskajā redakcijā. Rīga: Tiesu namu aǵentūra, 2013, 268. lpp.

28 Administratīvā procesa likuma komentāri. A un B daḷa. Autoru kolektīvs. Dr. iur. J. Briedes zinātniskajā redakcijā. Rīga: Tiesu namu aǵentūra, 2013, 268. lpp.

${ }^{29}$ Leja M. Krimināltiesību aktuālie jautājumi un to risinājumi Latvijā, Austrijā, Šveicē un Vācijā. Rīga: Tiesu namu aǵentūra, 2019, 170.-171., 213. lpp.

30 Turpat, 195.-196. lpp. 
saturu noteikt atbilstoši attiecīgā normatīvā tiesību akta un arī tiesību sistēmas kopējiem mērḳiem. ${ }^{31}$

Pirmkārt, izvērtējot KL pamata redakcijā ietvertos noziedzīgo nodarījumu sastāvus, secināms, ka preču nelegālas starptautiskas aprites kontekstā bija kriminalizēta tikai kontrabanda kā preču nelikumīga pārvietošana pāri Latvijas Republikas muitas robežai (KL 190. pants) un turpmākā rīcība iekšzemē ar kontrabandas ceḷā ievestajām precēm (KL 191. pants). Savukārt muitas procedūru pārkāpumi expressis verbis nebija kriminalizēti, lai gan par tiem vienmēr bijusi paredzēta administrativā atbildība. N̦emot vērā, ka kontrabandas un muitas procedūru pārkāpumu gadījumos iespējams nodarìt līdzvērtīgi būtisku kaitējumu tautsaimniecībai, likumdevējam nebūtu pamata sodus par tiem paredzēt atšḳirīgu sodu sistēmu ietvaros.

Vērtējot kasācijas instances tiesas līdzšinējo praksi, bija secināms, ka, tās ieskatā, muitas procedūru pārkāpumi kvalificējami kontrabandas kontekstā. ${ }^{32}$ Savukārt no apskatāmajiem nolēmumiem tikai netieši izriet, ka šajos gadijumos tomēr ir piemērojams KL 191. pants. Tādējādi kasācijas instances tiesa nav paudusi nepārprotamu nostāju par muitas procedūru pārkāpumu kriminalizēšanu un kvalificēšanu.

Otrkārt, rīcība ar precēm, kas kontrabandas rezultātā ievestas Latvijas Republikas teritorijā, ir atzīstama par rīcību ar noziedzīgi iegūtu mantu. KL vienmēr bijusi paredzēta kriminālatbildība par rīcību ar noziedzīgi iegūtu mantu atbilstoši KL 195. pantam "Noziedzīgi iegūtu līdzekḷu legalizēšana” un KL 314. pantam "Noziedzīgā kārtā iegūtas mantas iegādāšanās un realizēšana" ${ }^{33}$. Tādēl izvēlei jau sākotnēji speciālā noziedzīga nodarījuma sastāvā kriminalizēt tieši rīcību ar kontrabandas ceḷā ievestām precēm trūka pamatojuma, it seviškí, kad maksimālā sankcija par KL 191. pantā un 314. pantā paredzētajiem noziedzīgajiem nodarījumiem bija vienāda. ${ }^{34}$

Ievērojot minētos argumentus, likumdevēja iecere jaunā redakcijā izteikt KL 191. pantu bija vērtējama pozitīvi, ja tajā tiek formulēts jauna noziedzīga nodarījuma sastāvs, proti, muitas procedūru noteikumu pārkāpumi. Mērḳtiecīgai preču starptautiskas aprites krimināltiesiskajai aizsardzībai tas būtu pamatoti un nepieciešami, jo tiktu paredzēta kriminālatbildība par pietiekami un salīdzināmi kaitīgiem nodarījumiem noteiktā tautsaimniecības jomā, proti, muitas darbības jomā, aptverot visu laika posmu, kad preces atrodas muitas uzraudzībā.

Aizvien dinamiskākā laikā dzīvojot, tikai būtiskāka kḷūst atziṇa, ka tiesību normas savu leg̣itimitāti gūst tagadnē, tās piemērojot jaunajos apstākḷos, kas atspoguḷo piedzīvotās izmaiṇas faktiskajā un tiesiskajā realitātē. ${ }^{35}$ Vienlaikus

31 Administratīvā procesa likuma komentāri. A un B daḷa. Autoru kolektīvs. Dr. iur. J. Briedes zinātniskajā redakcijā. Rīga: Tiesu namu aǵentūra, 2013, 272.-273. lpp.

32 Latvijas Republikas Augstākās tiesas Senāta Krimināllietu departaments 05.042005. lēmumā lietā Nr. SKK 01-187/05 skaidroja, ka preču ievešana valsts muitas teritorijā uzskatāma par nelikumīgu, ja attiecīga muitas procedūra ir uzsākta, bet nav pabeigta, kas raksturo muitas kontroles apiešanu.

33 Dr. habil. iur. U. Krastiņš tieši norādījis, ka manta atzīstama par iegūtu noziedzīgā kārtā, ja tā iegūta kontrabandas cel̦ā (Krastiņš U., Liholaja V., Niedre A. Krimināltiesības. Sevišķā daḷa. 3. papild. izd. Zinātniskais redaktors prof. U. Krastin̦š. Rīga: Tiesu namu aǵentūra, 2009, 737. lpp.).

34 Papildus norādāms, ka pie kriminālatbildības saskaņā ar KL 191. pantu nebija saucama persona, kura pati attiecīgās preces Latvijas Republikas teritorijā bija ievedusi vai bijusi kontrabandas izdarītāja līdzdalībniece, pretēji, kā tas ir KL 195. panta gadījumā (Krastiṇš U., Liholaja V., Niedre A. Krimināltiesības. Vispārīgā un sevišķā daḷa. Rīga: Tiesu namu aǵentūra, 1999, 236. lpp.).

35 Mel̦kisis E. Tiesību normu iztulkošana. Rīga: Latvijas Universitāte, 2000, 47., 52. lpp. 
likumdevējam kḷūst aizvien grūtāk tiesību normas formulēt vienkārši, sabalansējot indivīda prasību pēc normas vieglas uztveres un sabiedrisku nepieciešamību pilnībā nodrošināt tās mērḳa sasniegšanu. N̦emot vērā neizbēgamību, ka laika gaitā tiesību norma kḷūst aizvien patstāvīgāka, attālinoties no tās izstrādātāju priekšstatiem, ${ }^{36}$ tiesai saskan̄ā ar normas tekstu ir iespējams korigét tiesību normas izpratnes nepilnības, interpretējot to sistēmiski KL un speciālās tiesību nozares kontekstā, kā arī atbilstoši kriminālatbildības mērḳim, kas sasniedzams ar konkrēto tiesību normu.

\section{Kopsavilkums}

1. Krimināllikuma 191. panta kvalitāte tajā izdarīto grozījumu kontekstā ir diskutabla, jo savstarpēji izslēdzoši tā skaidrota gan tiesu praksē, gan juridiskajā literatūrā.

2. Tiesību normas kvalitātes trūkumi novēršami, interpretējot tiesību normu un tādējādi noskaidrojot tās satura un attiecīgi - piemērošanas robežas.

3. Atšķirīga vārdu izvēle nodarījuma formulēšanā (interpretācijas gramatiskais elements), salīdzinot ar iepriekšējo redakciju (interpretācijas vēsturiskais elements), pirmšķietami liecina par tiesîbu normas, tajā skaitā par noziedzīga nodarījuma sastāva, tvēruma izmainām. Noziedzīga nodarījuma sastāva sistēmiska interpretācija Krimināllikumā un attiecīgajā tiesību nozarē nosaka pilnvērtīgu un efektīvu konkrētās intereses krimināltiesisko aizsardzību, nodrošinot noziedzīgā nodarījuma sastāva mērḳa sasniegšanu (interpretācijas teleologiskais elements).

4. Krimināllikuma 191. pantā paredzama atbildība par muitas procedūru noteikumu pārkāpumiem, rīkojoties ar precēm bez muitas iestāžu aț̣aujas pēc tam, kad preces pāri muitas robežai ir pārvietotas tiesiski. Attiecīgi noziedzīgā nodarījuma priekšmets ir deklarējamas preces, kuras ir uzrādītas muitas iestādēm un kurām ir piemērota kāda muitas procedūra.

5. Krimināllikuma 191. panta gramatiska, sistēmiska un teleologiska interpretācija liecina par to, ka tajā vairs nav paredzēta kriminālatbildība par rīcību ar tādām muitošanai pakḷautām precēm, kuras Latvijas Republikā kā ES dalībvalstī nogādātas, iepriekš nelegāli šķērsojot ES un trešās valsts muitas robežu.

6. KL 191. pants ir speciāla tiesību norma iepretī KL 221. pantam, kas noteic, ka kriminālatbildība paredzama par jebkādu nelikumīgu rīcību ar Latvijas Republikas teritorijā esošiem alkoholiskajiem dzērieniem un tabakas izstrādājumiem, kuriem nav piemērota kāda muitas procedūras un kuri neatrodas muitas uzraudzībā.

${ }^{36}$ Turpat, 6. lpp. 